\title{
Legal Responsibility of Jiwasraya Insurance Companies to Customers
}

\author{
Fransisca Anri Widyani ${ }^{1}$, Rr.Ani Wijayati ${ }^{2}$ \\ \{ani.wijayati@uki.ac.id\} \\ Universitas Kristen Indonesia ${ }^{12}$
}

\begin{abstract}
The concept of insurance implies the existence of a risk whose occurrence cannot be ascertained and the delegation of responsibility to bear the burden of risk from the party who has the risk to another party who is able to take over the responsibility. Insurance institutions, apart from being risk transfer institutions, are also institutions that absorb funds from the public through premium payments. The insurance business is a business that is full of trust and high-risk business. The case of failure to pay claims of PT Asuransi Jiwasraya (Persero) is not only an indication of state losses but also losses suffered by policyholders (customers). The cause of the default was an error in the management of customer funds, starting from the collection of funds for the JS Proteksi Plan product and the occurrence of irregularities in the asset investment process which allegedly contained unlawful acts. Asuransi Jiwasraya (Persero) has legal responsibility for losses suffered by customers as policyholders.
\end{abstract}

Keywords: Insurance companies; customers; legal responsibility

\section{Introduction}

Insurance develops along with the times. Various types of insurance are offered to the public, and this means that people tend to have a high sense of trust in insurance companies, and this can also be evidence that people are aware of the importance of insurance in anticipating risks that may occur in the future [1]. Insurance is an agreement between two parties, namely the insurer and the insured. In this case, the insured is the customer and the insurer is the insurance company. This agreement is a risk transfer agreement experienced by the insured, by paying a premium, the risk can be transferred to the insurer. The risk that can be transferred is in the form of accidents, natural disasters, and even death depending on the object of the agreement. From this, it can be said that there are several kinds of risks that can happen to anyone, both individuals and business actors. For business actors who already have experience in managing their business as well as for professionals, for the risks they want to experience in carrying out their daily activities, in general, they do not manage them by themselves but are transferred to other parties, in this case, known as insurance institutions [2].

In-Law no. 40 of 2014 concerning Insurance states that insurance is an agreement between two parties, namely the insurance company and the policyholder, which is the basis for receiving premiums by the insurance company in return for: a. provide compensation to the insured or policyholder due to loss, damage, costs incurred, loss of profit, or legal liability to third parties that may be suffered by the insured or policyholder due to the occurrence of an uncertain event; or b. provide payments based on the death of the insured or payments based on the life of the 
insured with benefits whose amount has been determined and/or based on the results of fund management.

PT. Asuransi Jiwasraya (Persero) is the first insurance company in Indonesia which was founded in 1859 under the name Nederlandsch Indiesche Levensverzekering en Liffrente Maatchappij van 1859 (NILLMIJ). PT. Asuransi Jiwasraya was born with the noble idea of educating the public to plan for the future. It is a big idea that has been recognized by the pioneers, founders, and policymakers of this republic for more than 152 years. To carry out this noble task, Jiwasraya mobilizes all its dedication and expertise in meeting the demands of the community for life insurance and financial planning which are increasingly complex and competitive [3].

PT Jiwasraya is an insurance company that oversees several companies and provides guarantees to the public or customers who are part of the company. In addition, the role of the Financial Services Authority (OJK) in the supervision of PT Jiwasraya, Jiwasraya has been recognized since 2004. This has been known since Jiwasraya reported it to the Capital Market and Financial Institution Supervisory Agency (Bapepam LK) which later changed to become part of OJK. The company reported smaller reserves than it should have. For this condition, the Supreme Audit Agency (BPK) gave a disclaimer opinion on Jiwasraya's 2006 and 2007 financial statements. At the end of 2018 PT. Asuransi Jiwasraya faces liquidity pressures that cause delays in the value of disbursement of claims against insurance policyholders.

On January 14, 2020, the Attorney General's Office (AGO) detained 5 (five) people suspected of being involved in the Jiwasraya case, 3 (three) of whom were former directors of PT. Asuransi Jiwasraya (Jiwasraya) are Hendrisman Rahim (Former Director), Harry Prasetyo (Former Finance Director), and Syamirwan (Former Head of Investment and Finance Division). The three were charged with violating Article 2 and Article 3 of Law no. 20 of 2001 concerning Amendments to Law no. 31 of 1999 concerning the Crime of Corruption (UU Tipikor). The detention was carried out based on the results of an investigation by the Supreme Audit Agency (BPK) which found allegations of corporate crime in the management of the company involving the board of directors, managers, and other parties outside the company.

In 2016, BPK actually revealed 16 (sixteen) findings indicating that there had been a violation of the law, but it was only in June 2019 that the Prosecutor's Office began to investigate this case. This corporate crime is strongly suspected of being the cause of Jiwasraya's failure to pay its customers a total of IDR 802 billion (October 2018) and IDR 12.4 trillion (December 2019). In 2019, it is suspected that the cause of the inability to pay claims experienced by PT. Asuransi Jiwasraya was caused by liquidity pressures that occurred due to investment errors. In the period 2007 to 2012, the insurance company placed its funds in a stock repo. A repo transaction (repurchase agreement) is a loan given as collateral in the form of shares. Loans like this offer high interest considering the risk are also high.

Problems arise when the stock market weakens and stock prices plummet. The company cannot sell the shares that are collateral for the credit because the value has decreased. Insurance companies as credit lenders, if they don't sell, sell guarantees at prices when prices are low [4]. This condition is certainly troubling for its 7.7 million customers (Bisnis.tempo.co, January 13, 2020). Based on the results of the 2016 Jiwasraya examination and the results of the 2018 investigation, BPK concluded that there had been deviations from the law in collecting funds from the JS Savings Plan product and placing investments in the form of shares and funds, resulting in a negative spread that eroded Jiwasraya's assets and resulted in losses. A saving plan is a life insurance product with the purpose of providing protection in the form of death or total permanent disability protection because it provides other benefits, namely investment guarantees as well as guaranteed principal and investment returns [5]. 
Mistakes also occur in investing in stocks and mutual funds without adequate placement studies. The law enforcement officer authorized to impose this sanction is the Financial Services Authority (OJK). The weakness of the OJK's supervisory function on the implementation of its functions and duties as well as regulations that are in the form of actions can provide strict sanctions to the OJK so that when a problem occurs that arises from the negligence of supervision by the OJK, this cannot be separated from the lack of legal regulations regarding sanctions for OJK's negligence. in carrying out their duties to cause losses to customers and the state.

This is certainly very detrimental to the policyholder because the main purpose of the policyholder is to use insurance to protect himself from the unexpected, but in the case of submitting a claim to the insurance company, it cannot make payments for the transfer of risk which has become an obligation in the insurance agreement. The insurance company as the insurer has an obligation [6]

1. Provide compensation or provide a sum of money to the insured if the agreed event occurs, unless there is something to be used as a reason for the insurance company to be free from the obligation.

2. Sign the policy and submit it directly to the insured.

3. Return the premium to the insured if the insurance is cancelled or cancelled, provided that the insured has not covered the risk in part or in full.

4. In fire insurance, the insurer is obliged to bear the costs of the loss needed to rebuild if the agreement or policy states this.

In the above provisions, it is clear that the insurance company is obliged to provide compensation to the insured or the policyholder if the event occurs, but when the insured submits a claim to the insurance company, the company states that they are unable to pay. Based on the background above, the author raises the issue of "Legal Responsibility of Life Insurance Companies to Customers"

\section{Results and Discussion}

In 2018 and 2019 PT Jiwasraya has filed a default against a number of its customers, some of the aggrieved customers have filed a default lawsuit to the court. So that the efforts made by the aggrieved customer are in order to get legal protection for what is caused by PT Jiwasraya which results in a loss. The results of investigations from law enforcement officers, namely the Prosecutor's Office and the Police, found that there were many parties involved in the Jiwasraya case, and the various regulations that were violated in the Jiwasraya case made legal settlements take a long time.

To shorten and optimize the investigation and investigator process, law enforcement officers can provide criminal, civil, administrative, and ethical protection at the same time for the parties involved in the violation. The formation of a working committee (panja) by several commissions in the House of Representatives (DPR) can revise the OJK Law related to strengthening sanctions against OJK officials/employees who are negligent in carrying out their duties and synchronize the investigation rules in the Capital Market Law with the OJK Law.

The statutory regulations that are side by side in the Jiwasraya case are as follows:

1. Article 2 of the Anti-Corruption Law relates to acts of enriching oneself, another person, or a corporation, and Article 3 of the Anti-Corruption Law relates to abuse of authority that can harm state finances or the state economy. According to BPK in marketing the JS saving 
plant product, it is suspected that the parties involved in PT Jiwasraya received a fee for selling the product. This action can indicate corruption because PT Jiwasraya is a StateOwned Enterprise (BUMN). The law enforcers who can apply this rule are the police, prosecutors, and the Corruption Eradication Commission (KPK).

2. Article 3 of Law no. 8 of 2010 concerning the Prevention and Eradication of the Crime of Money Laundering (UU TPPU) concerning the prohibition of hiding or disguising the proceeds of corruption. Violation of this provision is punishable by a maximum imprisonment of 20 years and a maximum fine of Rp. 10 billion. Currently, the Attorney General's Office (AGO) has collaborated with PPATK to track the flow of Jiwasraya's corruption funds. In addition to the Prosecutor's Office, ML cases can be handled by the police and the KPK.

3. Article 11 and Article 21 of Law no. 40 of 2014 concerning insurance (Insurance Law). Article 11 regulates the obligation of good governance for insurance companies. Article 21 paragraph (3) stipulates that in investing the assets of customers, insurance companies are required to apply the precautionary principle. Because violations of these two articles are subject to administrative sanctions in the form of warnings, business restrictions, prohibitions on product marketing, revocation of licenses, cancellation of registrations and approvals, administrative fines, and/or prohibitions from occupying certain positions.

4. Article 97 paragraph (3) of Law no. 40 of 2007 concerning Limited Liability Companies (PT) which regulates the personal liability of directors. In the Jiwasraya case,

5. Article 32 paragraph (1) of Law no. 21 of 2011 concerning the Financial Services Authority (OJK Law), which stipulates that if OJK officials/employees are found to be involved in a case, the board of commissioners will enforce a code of ethics. Then if there are indications of corruption, the KPK can intervene (Article 11 of Law No. 30 of 2002 concerning the Corruption Eradication Commission).

6. Article 90 of Law no. 8 of 1995 concerning the Capital Market (Capital Market Law, prohibits the existence of criminal acts of fraud in the capital market. This Capital Market Law threatens with a maximum imprisonment of 10 years and a maximum fine of Rp. 15 billion.

7. Article 30 of Law no. 5 of 2011 concerning Public Accountants (Public Accountants Law) which prohibits public accountants from receiving conditional compensation, receiving commissions, and manipulating. If the prohibition is violated, the public accountant is threatened with administrative sanctions in the form of recommendations to carry out certain obligations, written warnings, restrictions on the provision of services, freezing, revocation of permits, and fines. Administrative sanctions are given by the Minister of Finance.

8. Article 17 Financial Services Authority Regulation No. 73/POJK 05/2016 concerning Good Corporate Governance for insurance companies (POJK No. 73/POJK.05/2016), prohibiting directors from conducting transactions that have conflicts of interest, taking advantage of positions and/or receiving personal benefits from the company [7]

In resolving the dispute, Jiwasraya has violated so many laws and regulations. So it is hoped that the settlement of the Jiwasraya case will be carried out with transparency and confiscate/impoverish the perpetrators who have violated the 8 (eight) laws and regulations in order to replace customer losses and also state losses and provide punishment as a form of guidance. This is done as a revolutionary step to answer the problem of crime. Customers are "consumers as providers of funds", while the definition of a customer according to the Big Indonesian Dictionary is a person who is used to dealing with or being a bank customer (in terms of finance), a customer can also be interpreted as a depositor as well as a party who puts 
money in a bank as deposits based on agreements between banks and customers [8]. These customers have an important role in the rapid economic development that has produced various types and variations of each type of goods and/or services that can be consumed. These goods and/or services are generally goods and/or services that are similar or complementary to one another [9]. Customers or consumers must be guaranteed and protected by law.

Indonesia is a state of law, so it is very important to provide legal protection for its citizens. Customers are citizens whose rights must be protected by the state, so the legal protection carried out by the state, namely the regulation of legal protection for customers, is a basic constitutional right. UU no. 39 of 1999 concerning Human Rights (HAM) in Article 17 which states that "Everyone, without discrimination, has the right to obtain justice by submitting applications, complaints, and lawsuits, in criminal, civil and administrative cases and being tried through a judicial process that free and impartial, under the procedural law which guarantees an objective examination by an honest and fair judge to obtain a fair and correct decision.

From Law no. 8 of 1999 concerning Consumer Protection, protection can also be born from an agreement between parties that have legal relations with one another. Both the agreement made and agreed upon by the parties and the law made by the legislator, both of which form an agreement between the parties who make it. An engagement that determines the rights and obligations that must be carried out or not to be performed by one of the parties to the engagement [10].

However, over time the liquidity crisis experienced by Jiwasraya and Bumiputera reached Rp 50 trillion so that in protecting the rights of these 12 (twelve) million insurance consumers, BPKN asked the state to restore consumer rights and carry out law enforcement processes for violations committed by these companies. In addition, BPKN sees mismanagement in the management of Bumiputera and Jiwasraya. Then what are the steps of BPKN in protecting consumer rights in this case? [11]. Legal protection and liability for customers or consumers is an obligation of the state. In practice, the basis of coverage is the economic motive, although it is recognized that there are other motives, namely social security, and legal protection, which are humanitarian in nature.

The handling of cases of PT Asuransi Jiwasraya (Persero) is focused on efforts to refund customers' money. It is feared that the effort to form a Special Committee (Pansus) is only to make this case a mere political commodity and does not guarantee the refund of customers' money. This is because the State of Indonesia has the characteristics of a state of law so that every act that violates the law must be accounted for [12]. Protection for consumers in the financial services sector aims to create a reliable consumer protection system, increase consumer empowerment, and raise awareness of financial services business actors regarding the importance of consumer protection to increase public confidence in the financial services sector.

Based on Article 2 of the Financial Services Authority Regulation Number 1/POJK.07/2013 concerning Consumer Protection in the Financial Services Sector (POJK 2013) there are 5 (five) principles, namely [13]: transparency, fair treatment, reliability, confidentiality, and security of consumer data/information and complaint handling and consumer dispute resolution at a simple, fast, and affordable cost.

Along with this, business actors operating within the scope of insurance are required to provide customers with information about products and services that are accurate, honest, clear, and not misleading. So that these customers can get services and social security for their rights as customers, because this is a necessity or obligation of the state, namely the government to be able to provide protection for citizens in order to achieve the ideals of the state, namely social justice for all Indonesian people. 
Legal protection is the protection of the human rights of those who are harmed by law enforcement officers so that the community can enjoy all the rights granted by law for the sake of creating a sense of security, both mentally and physically from interference and threats from any party [14]. Jiwasraya customers as aggrieved parties are certainly entitled to legal protection. There are 4 (four) forms of repressive legal protection that can be provided by law enforcement officers in this case, namely:

1. Legal protection from the criminal aspect, namely by criminally processing parties who cause state losses in Jiwasraya. Currently, the AGO has named several parties as suspects based on Article 2 and Article 3 of the Anti-Corruption Law. The AGO is also working with PPATK to track down Jiwasraya's assets as well as to look for evidence related to the Crime of Money Laundering (TPPU). The use of the ML article, in this case, is very good because with ML the suspects can be subject to criminal penalties in the form of replacement money. The KPK can be involved in this case, especially if it involves law enforcement officers and state administrators, disturbs the public, and/or causes a loss of at least IDR 1 billion (Article 11 of the KPK Law).

2. Legal protection from the civil aspect, legal protection can be carried out in 2 (two) ways, namely ordinary civil lawsuits or bankruptcy. Civil legal protection can be provided by the judge handling the case. Civil lawsuits can be filed against the directors, commissioners, and shareholders of Jiwasraya if it is proven that the person concerned has taken actions that harm the company or piercing the corporate veil. Currently, several customers have filed a breach of contract against Jiwasraya. While bankruptcy can be filed by Jiwasraya customers, it's just that the settlement through bankruptcy is very detrimental to insurance customers because in practice the customer's position is only as a concurrent creditor who will get repayment after labor wages, separatist creditors, and preferred creditors (Luthvi, 2017:262).

3. Legal protection from the administrative aspect. Violation of governance rules in POJK No. 73/POJK.05/2016 allows OJK to impose administrative sanctions on Jiwasraya. Public accountants involved are also threatened with administrative sanctions by the Minister of Finance.

4. Aspects of ethical responsibility, especially related to violations committed by OJK officials and employees. The imposition of ethical sanctions will be carried out by the OJK Board of Commissioners.

\section{Conclusion}

Protection of customers is something that must be done and provided by the state. Because the right to protection is a constitutional right guaranteed by the Constitution and the Law. handling cases of PT Asuransi Jiwasraya (Persero) focused on efforts to refund customers' money. In practice, the OJK as a supervisory agency has been negligent in carrying out its functions. This can be seen in 2018 and 2019 PT Jiwasraya has announced a default for its customers and has caused losses to state money.

However, in negligence committed by OJK itself, there are no sanctions or penalties for OJK, because there are no laws and regulations that have not regulated it. The state, in this case, is expected to be able to respond to this problem, by carrying out legal reforms to establish binding laws for the OJK for negligence committed by the OJK in order to achieve integration in the supervisory process carried out by the OJK and achieve justice in legal certainty. 


\section{References}

[1] Arus Akbar Silondae dan Andi Fariana, 2013. Aspek Hukum dalam Ekonomi dan Bisnis, Jakarta:Mitra Wacana Media.

[2] Sentosa Sembiring, 2014, Hukum Asuransi, Bandung,Nuansa Aulia.

[3] "Jiwasraya dan Asuransi Syariah", Republika, 13 Januari 2020, hal. 6.

[4] Afrezi Fitra, Salah Investasi Jiwasraya yang Berujung Gagal Bayar,diakses darihttps://katadata.co.id/telaah/2018/10/23/salah-investasi-jiwasraya-yang-berujung-gagal-bayar, pada Sabtu, 9 November 2019

[5] Jiwasraya, Sejarah Jiwasraya, https://jiwasraya.co.id/?q=id/sejarah-jiwasraya, pada Sabtu, 9 November 2019

[6] Man Suparaman Sastrawidjaja, 2003, Aspek-Aspek Hukum Asuransi dan Surat Berharga, Bandung, Alumni.

[7] Perlindungan hukum terhadap nasabah Jiwasraya, Luthvi Febryka Nola, https://www.google.comberkas.dpr. go., diakses pada tanngal 17 maret 2020, pukul 14.42 W.I.B.

[8] I.G. Rai Widjaya,2000, Hukum Perusahaan Terbatas Khusus Pemahaman Atas undang-Undang No. 1 Tahun 1995, Megapoin, Jakarta.

[9] Gunawan Widjaja dan Ahmad Yani, 2003, Hukum Tentang Perliindungan Konsumen”, Jakarta, PT Gramedia Pustaka Utama.

[10] A. Mukthie Fadjar, 2018, Negara Hukum dan Perkembangan Teori Hukum, Sejarah dan Pergesar Hukum, Malang, Intrans Publishing.

[11] Abdulkadir Muhammad, 1990, PokokPokok Hukum Pertanggungan, Bandung, PT Citra Aditya Bakti.

[12] Explanation of the Case of PT Asuransi Jiwasraya (Persero) from KAP-KAP Conducting Engagements in 2015, 2016 and 2017, Jakarta, 21 December 2018, https://iapi.or.id/Iapi/detail/580, Accessed on March 27, 2020, at 13.23 WIB.

[13] Trisadini Prasastinah Usanti, Journal : Kajian Hukum \& Keadilan, Perlindungan Hukum Bagi Nasabah Perusahaan Pergadaian.

[14] Satjipto Rahardjo, 2012, Ilmu Hukum, Bandung, Citra Aditya Bakti.

[15] Iwan Setiawan, Bedah Kasus Gagal Bayar dan Kerugian Asuransi Jiwasraya, Jabisi (jurnal Akuntansi dan Bisnis Indonesia)

[16] "BPK Telusuri Transaksi Sampai ke Pengawas Jiwasraya", 13 Januari2020, https://bisnis.tempo.co/ $\mathrm{read} / 1294261 / \mathrm{bpk}$-telusuri- transaksi-sampai-ke-pengawas-j i w a s r a y a / f u 11 \& v i e w = o k ,diakses 20 Januari 2020.

[17] Jiwasraya, Proteksi J $\quad$ Plan, diakses https://www.jiwasraya.co.id/?q=id/product/bancassurance/js-proteksi-plan, pada Sabtu, 9 November 2019

[18] "Kementerian BUMN Bongkar Kronologi Gagal Bayar Jiwasraya", https://www.cnnindonesia.com/ekonomi/20191226140440-78-460053/kementerian-bumnbongkar-kronologi-gagal-bayar-jiwasraya, diakses 29 Januari 2020. 